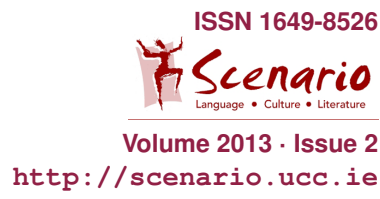

TaT - Texts around Theatre - TaT

\title{
Home Before Night
}

\section{Hugh Leonard}

In this rubric we present various perspectives on theatre - historical and contemporary, intercultural and culture-specific, unexpectedly weird, unusually suspenseful, disturbedly gripping, fascinatingly enigmatic ...

In this autobiographical text, Irish author Hugh Leonard remembers moments from his youth that triggered his curiosity for theatre and set the course for his later career as a playwright/dramatist.

Every morning when you came in, you signed the attendance book, and $\mathrm{Mr}$ Drumm would carry it off to his own table to mark the names of the latecomers in red ink. One day, he made to pick up the book, then looked closely at it. 'Come here and sign your name, Mr Kennedy,' he said.

'Oh, I signed me name,' Mr Kennedy said without budging from his chair, and sure enough Jack had seen him bending over the book with a pencil in his hand.

'You did not sign your name,' Mr Drumm said. 'You will come here and do so now.'

'Oh, I signed it right enough,' Mr Kennedy said happily. A redness was spreading into Mr Drumm's face. 'And I tell you you did not. Now sign this book or be marked absent.' Mr Kennedy just grinned as if he was too cute to fall for an old trick the like of theat. Mr Drumm's finger stabbed at the book like the needle of a sewing machine. His voice was hoarse with rage. 'Do as I say!' There was a hush in the room as Mr Kennedy got up from his table, taking with him the magnifying glass he used for reading. He was bent over the book for a long time, and when he straightened up his face threw a pink, happy light on Mr Drumm. 'Ah,' he said, 'did you rub it out on me?' At first, Jack had thought that the people around him were mummies that needed burying, but before long he realised that he was in an orchestra of head cases, with Mr Drumm as the conductor. He could never be as unhappy again as he had been on that first day, but more than ever he longed to be free of the place. He had been there for six months when a man named Paddy Malone remarked to him: 'A great ending to a great play.'

'What is?'

"That tune you were whistling: "Keep the Home fires Burning". It comes in at the end of the Plough and the Stars. You know: by O'Casey.'

He shook his head.

'You what? You call yourself a Dublin man and you never heard tell of O'Casey?'

'Well, yeah, I heard of him, but-' 
'Lord God, I'm from Cork where they eat their young, yet I know him backwards. And you the fellow with his nose forever stuck in a book. What are you reading there, anyway?' He picked up a book from Jack's table. 'The Garden by L.A.G. Strong.' He grunted. He had fair hair, turning iron grey. His mouth was set in a pretended disgust. 'Are you having me on or what? You never heard of The Plough and the Stars?'

'No.'

'And you're the man who wants to write books?'

Someone had been spreading yarns. 'I never said I -

'Listen to me. It's on at the Abbey, so would you ever go down there and see it and not be making a holy show of yourself.' He winked and strolled away, singing 'Keep the Home Fires Burning' in a Cork tenor that made Mr Drumm's eyes swing around like searchlights.

That evening, Jack went to the Abbey Theatre. He had never seen a play before, except for The Colleen Bawn in Dalkey town hall, where the girl was thrown off the rock into the lakes of Killarney, and all the hard chaws had stood up to see her land on a mattress. Now, he saw and actor named McCormick, who was as real as Mr Quirk in Kalafat Lane had been, or Jack's uncle Sonny, or any of the old lads who stood spitting at Gilbey's corner or the harbour wall: A foxy faced jackeen in a hard hat, who would look to gut you one minute and be decent skin the next. And there was a young actor named Cusack who was the Young Covey, and when he changed out of his working clothes and remembered to take the packet of Woodbines from his overall pocket, the people nudged one another and whispered: 'Oh, that's very good.'

But it was more than the acting that made Jack stand outside the theatre afterwards, looking towards the roof tops for the red glow of Dublin burning that he had seen through the window of Bessie Burgess's attic room. The life that roared through the play itself had spilled over the stage, sweeping him with it so that he knew he would never again be content just to sit and watch and applaud with the rest of them. The thought burned him like fever.

He went along Marlborough Street to the quays, and from the dark of the river the east wind leaped at him like a rover. He held his coat collar shut, and his hand shook with cold. He went trotting past the row of handsome cabs and the snorting horses, racing the lights of the last train as it crossed the loop line bridge to Tara Street. The guard held the door of the last compartment open for him, and he sat down opposite a young man and a girl. The man looked sulkily at him: by interloping Jack had spoiled his chance of a court.

The pair of them could strip to their skins for all he cared. He looked away from them through the window and saw his reflection in the dark glass. It was amazing how calm he looked. His breath in the unheated compartment threw a mist upon the glass, but even then he could see, as if it was out there by the tracks, the door he would escape through. 
From: Hugh Leonard: Home before Night. London 2002, Methuen, 179 181 